\title{
ChemComm
}

\section{Rhodium-catalyzed arylative cyclization of alkynyl malonates by 1,4-rhodium(I) migration $†$}

Received 00th January 20xx, Accepted 00th January 20xx

DOI: $10.1039 / x 0 \times x 00000 x$

\author{
Luke O’Brien, ${ }^{\text {ab }}$ Somnath Narayan Karad, ${ }^{\text {ab }}$ William Lewis, ${ }^{b}$ and Hon Wai Lam*ab
}

www.rsc.org/

The synthesis of functionalized 1-tetralones by the rhodium(I)catalyzed reaction of alkynyl malonates with arylboronic acids is described. These arylative cyclizations proceed via an alkenyl-toaryl 1,4-Rh(I) migration as a key step. Preliminary results of an enantioselective variant of these reactions are also presented.

Domino reactions that consist of a metal-catalyzed addition of an aryl nucleophile to an alkyne, followed by an intramolecular nucleophilic addition of the resulting alkenylmetal species onto a tethered electrophile, are versatile transformations for the preparation of hetero- and carbocyclic products. ${ }^{1}$ A variation of these arylative cyclizations involves the 1,4-migration of the metal ${ }^{2}$ from the initially formed alkenylmetal species $\mathbf{A}$ onto an aryl site, followed by cyclization of the resulting arylmetal species $\mathbf{B}$ onto the electrophile (Scheme 1A). This through-space transmission of reactivity further increases the synthetic capabilities of arylative cyclizations, and to date, reactions based upon alkenyl-to-aryl 1,4-

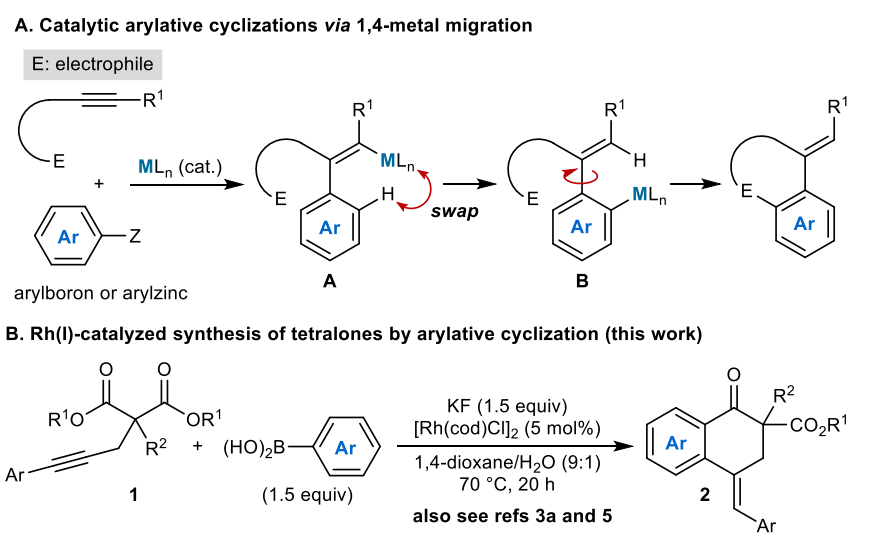

Scheme 1 Catalytic arylative cyclizations via 1,4-metal migration

a. The GlaxoSmithKline Carbon Neutral Laboratories for Sustainable Chemistry, University of Nottingham, Jubilee Campus, Triumph Road, Nottingham, NG7 2TU, United Kingdom

b. School of Chemistry, University of Nottingham, University Park, Nottingham, NG7 2RD, United Kingdom

+ Electronic Supplementary Information (ESI) available: Experimental procedures, full spectroscopic data for new compounds, and crystallographic data for 2ea. CCDC 1938497. See DOI: 10.1039/x0xx00000x

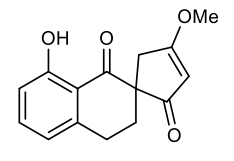

(士)-nidemone

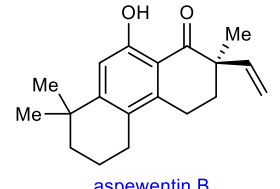

aspewentin B

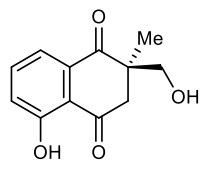

diomuscinone
Fig 1 Natural products containing a 1-tetralone with an all-carbon quaternary stereocenter at C2

migrations of rhodium, ${ }^{3}$ iridium, ${ }^{4}$ and cobalt $^{5}$ have been described. ${ }^{6,7,8,9,10,11}$ The use of esters as the electrophiles in these reactions leads to the formation of aromatic ketones. In this context, the Murakami $^{3 a}$ and Yoshikai $^{5}$ groups have shown that alkynetethered esters react with arylboron and arylzinc reagents in arylative cyclizations under rhodium and cobalt catalysis, respectively. However, only symmetrical alkynes were employed in these studies. $^{3 a, 5}$ Although this feature eliminates the challenge of controlling regioselectivity in the initial arylmetalation, it does limit synthetic utility. Here, we describe the rhodium-catalyzed reaction of arylboronic acids with alkynyl malonates $\mathbf{1}$, in which the alkyne is unsymmetrically substituted (Scheme 1B). These arylative cyclizations produce 1-tetralones containing an all-carbon quaternary stereocenter at $\mathrm{C} 2$, a structural motif that appears in several natural products such as $( \pm)$-nidemone, ${ }^{12}$ aspewentin $\mathrm{B},{ }^{13}$ and diomuscinone $^{14}$ (Figure 1). Preliminary results of an enantioselective variant are also described.

It is known that carbometalation of alkynes substituted with one alkyl and one aryl group are often highly regioselective. ${ }^{15}$ Accordingly, bis(2,2,2-trifluoroethyl)malonate 1a, which contains such an alkyne, was selected for our initial experiments in the hope that a highly regioselective synthesis of 1-tetralones by arylative cyclization could be achieved. First, a mixture of $1 \mathrm{a}$ and $\mathrm{PhB}(\mathrm{OH})_{2}$ (1.5 equiv) was heated at $70{ }^{\circ} \mathrm{C}$ for $20 \mathrm{~h}$ in the presence of $5 \mathrm{~mol} \%$ of $[\mathrm{Rh}(\mathrm{cod}) \mathrm{Cl}]_{2}$ and various bases (1.5 equiv) (Table 1$) .{ }^{16}$ We were pleased to observe that arylative cyclization was successful and the best results were obtained using $\mathrm{KF}$ as the base in 1,4-dioxane/ $\mathrm{H}_{2} \mathrm{O}$ (9:1) as the solvent, which gave 1-tetralone 2aa in $75 \%$ yield as determined by ${ }^{1} \mathrm{H}$ NMR analysis of the crude mixture using 1,4dimethoxybenzene as an internal standard (entry 1). This experiment also gave alkyne hydroarylation product 3 ab in $14 \%$ yield. Changing the quantity of $\mathrm{H}_{2} \mathrm{O}$ in the reaction medium by using anhydrous 
Table 1 Evaluation of reaction conditions ${ }^{a}$
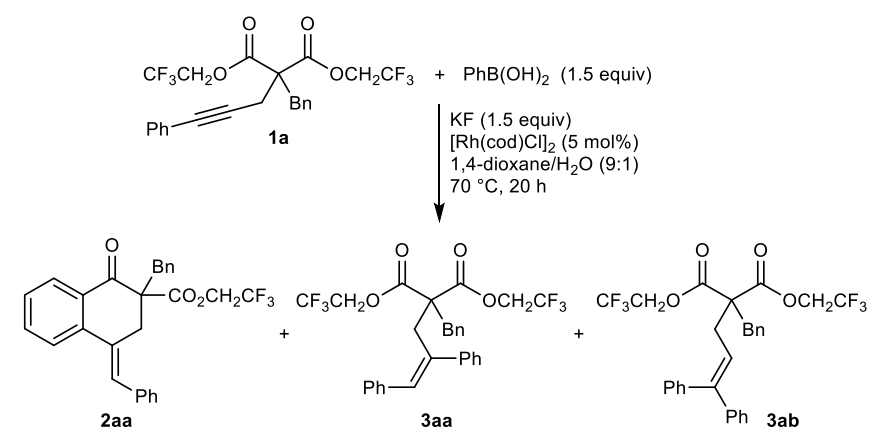

\begin{tabular}{lllll}
\hline Entry & $\begin{array}{l}\text { Deviation from } \\
\text { standard conditions }\end{array}$ & $\begin{array}{l}\text { Yield of 2aa } \\
(\%)^{b}\end{array}$ & $\begin{array}{l}\text { Yield of 3aa } \\
(\%)^{b}\end{array}$ & $\begin{array}{l}\text { Yield of 3ab } \\
(\%)^{b}\end{array}$ \\
\hline 1 & None & 75 & - & 14 \\
2 & 1,4-Dioxane as solvent & 42 & 19 & 14 \\
3 & In 1,4-dioxane/ $\mathrm{H}_{2} \mathrm{O}(4: 1)$ & 54 & 5 & 9 \\
4 & Toluene as solvent & 28 & 28 & 14 \\
5 & Xylenes as solvent & 33 & 42 & 14 \\
6 & $\mathrm{Et}_{3} \mathrm{~N} \mathrm{instead} \mathrm{of} \mathrm{KF}_{7} \mathrm{C}^{b}$ & 47 & 19 & 14 \\
7 & $\mathrm{Cs}_{2} \mathrm{CO}_{3}$ instead of KF & 56 & - & 9
\end{tabular}

${ }^{a}$ Reactions were conducted with $0.05 \mathrm{mmol}$ of 1 a. ${ }^{b}$ Determined by ${ }^{1} \mathrm{H}$ NMR analysis of the crude reactions using 1,4-dimethoxybenzene as an internal standard.

1,4-dioxane or 1,4-dioxane/ $\mathrm{H}_{2} \mathrm{O}$ (4:1) gave lower yields of $\mathbf{2 a a}$ along with significant quantities of alkyne hydroarylation products $\mathbf{3} \mathbf{a a}$ and 3ab (entries 2 and 3). Other solvents such as toluene (entry 4) and xylenes (entry 5) also gave inferior results. Other bases such as $\mathrm{Et}_{3} \mathrm{~N}$ (entry 6) and $\mathrm{Cs}_{2} \mathrm{CO}_{3}$ (entry 7) are also effective but the yields of 2aa are appreciably lower compared with using KF (entry 1). The conditions shown in entry 1 were therefore selected for use in further experiments.

The scope of this reaction with respect to the alkynyl malonate was then examined in reactions with $\mathrm{PhB}(\mathrm{OH})_{2}$, which gave 1tetralones 2aa-2qa in 33-74\% yield (Table 2). In some cases (2ha and 2pa), it proved beneficial to increase the loading of $[\mathrm{Rh}(\operatorname{cod}) \mathrm{Cl}]_{2}$ to $10 \mathrm{~mol} \%$ and the quantity of $\mathrm{PhB}(\mathrm{OH})_{2}$ to 2.0 equivalents. The reaction producing 2aa also gave a 1:1.25 mixture of inseparable alkyne hydroarylation products 3aa and 3ab (see Table 1 for the structures), respectively, in $19 \%$ combined yield. Alkyne hydroarylation products corresponding to $\mathbf{3 a a}$ and $\mathbf{3 a b}$ were not isolated in subsequent experiments using other substrates. The reaction is tolerant of a wide range of carbon-linked substituents at the 2-position of the substrate, including benzyl (2aa and $\mathbf{2 j a} \mathbf{\mathbf { a }}-\mathbf{2 m a}$ ), methyl (2ba and 2oa), 2-thienylmethyl (2ca), 2-oxo-2-phenylethyl (2da), 2-oxo-2-phenoxyethyl (2ea ${ }^{17}$ and 2na), phenyl (2fa), 2methoxyphenyl (2ga), 2-naphthyl (2ha), and 3-thienyl (2ia) groups. Heteroatom substituents at the 2-position are also accommodated, such as ethoxy (2pa) and 3-thienylmethoxy (2qa) groups. The alkynyl substituent can be changed from a phenyl group (2aa-2ia and 2na-2qa) to 4-methoxyphenyl (2ja), 3-methylphenyl (2ka), 1naphthyl (2la), and 2-thienyl (2ma) groups. A substrate with a methyl-substituted alkyne did undergo arylative cyclization in low yield but the product 2ra contained unidentified, inseparable impurities. ${ }^{18}$ In addition, a substrate containing a terminal alkyne gave only a complex mixture of unidentified products. Pleasingly, the reaction is not limited to bis(2,2,2-trifluoroethyl) malonates;
Table 2 Scope with respect to the alkynyl malonate ${ }^{a}$

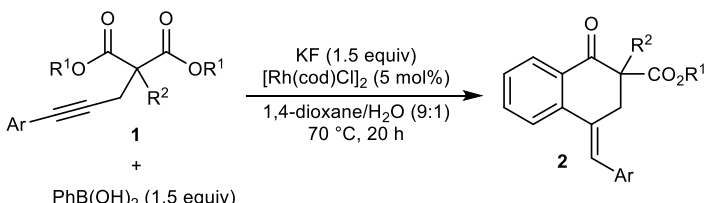

$\mathrm{PhB}(\mathrm{OH})_{2}(1.5$ equiv)
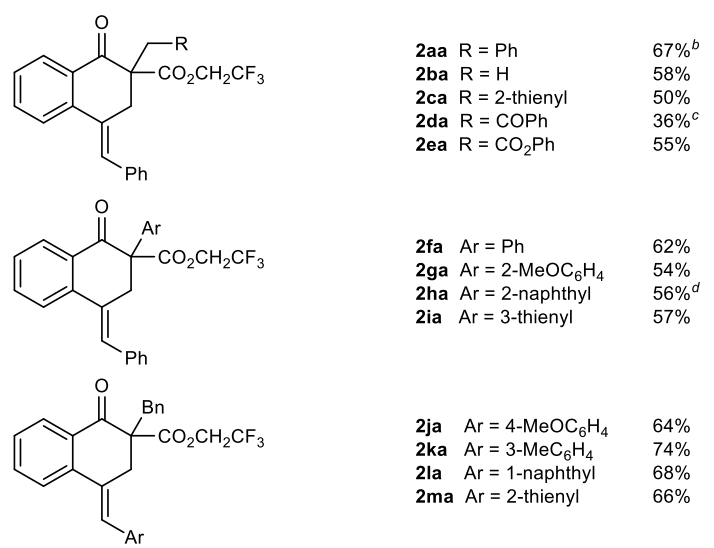<smiles>COC(=O)C1(CC(C)=O)C/C(=C\c2ccccc2)c2ccccc2C1=O</smiles>

2na

$72 \%$<smiles>O=C(O)C1(C(=O)Oc2ccccc2)C/C(=C\c2ccccc2)c2ccccc2C1=O</smiles>

2oa

$55 \%$<smiles>CCOC(=O)C1(C(F)(F)F)C/C(=C\c2ccccc2)c2ccccc2C1=O</smiles>

$2 \mathrm{pa}$

$36 \%^{d}$<smiles>O=C1c2ccccc2/C(=C/c2ccccc2)CC1(OCc1ccsc1)OCC(F)(F)F</smiles>

2q

$33 \%$

${ }^{a}$ Reactions were conducted with $0.30 \mathrm{mmol}$ of $\mathbf{1 a}-\mathbf{1 q}$ in $3 \mathrm{~mL}$ of 1,4 dioxane $/ \mathrm{H}_{2} \mathrm{O}(9: 1)$. Yields are of isolated products. ${ }^{b}$ This experiment also gave a 1:1.25 inseparable mixture of 3aa and 3ab, respectively, in 19\% combined yield. ${ }^{c}$ The reaction time was $24 \mathrm{~h} .{ }^{d}$ Conducted using $10 \mathrm{~mol} \%$ of $[\mathrm{Rh}(\operatorname{cod}) \mathrm{Cl}]_{2}$ and 2.0 equiv of $\mathrm{PhB}(\mathrm{OH})_{2}$

substrates containing dimethyl or diphenyl malonates gave 1tetralones 2na and 20 in $55 \%$ and $72 \%$ yield, respectively.

Table 3 presents the results of the reactions of representative substrates 1a, 1i, 1m, and 1n with various arylboronic acids, which gave 1-tetralones $\mathbf{2 a b}-\mathbf{2 n j}$ in $45-79 \%$ yield. The arylboronic acid scope includes a range of para- (2ab, 2ac, $2 \mathbf{n h}$, and $2 \mathbf{n i})$, meta(2mg), and disubstituted phenylboronic acids (2ie and $\mathbf{2 m f}$ ) containing methyl (2ab), halide (2ac, $2 \mathbf{m f}$, and $\mathbf{2 n i}$ ), carboethoxy (2mg), or alkoxy groups (2ge and 2nh). 2-Naphthylboronic acid (2ad) is also tolerated. In the case of 2-naphthylboronic acid and 3ethoxycarbonylphenylboronic acid, 1,4-Rh(I) migration occurred to the sterically more accessible position (2ad and $\mathbf{2} \mathbf{m g}$, respectively). 3-Thienylboronic acid also reacted successfully with 1a; however, 
Table 3 Scope with respect to the boronic acid ${ }^{a}$

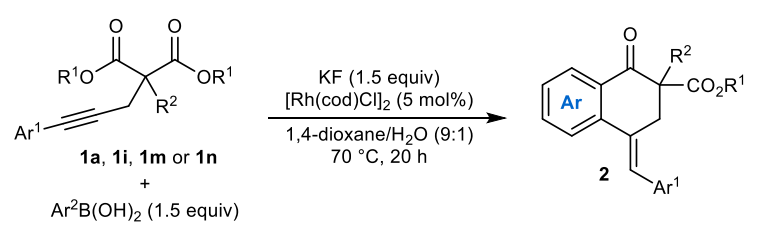<smiles>[R]c1ccc2c(c1)C(=O)C(Br)(C(=O)OCC(F)(F)F)C/C2=C\c1ccccc1</smiles>

$$
\begin{aligned}
& \text { 2ab } R=M e \\
& \text { 2ac } R=F \\
& \\
& \\
& \text { 2ad }
\end{aligned}
$$<smiles>O=C(CC(F)(F)F)C1(Cc2ccccc2)C/C(=C\c2ccccc2)c2cc3ccccc3cc2C1=O</smiles><smiles>COc1cc2c(cc1OC)/C(=C/c1ccccc1)CC(C(=O)OCC(F)F)(c1ccsc1)C2=O</smiles>

2ie

$50 \%$<smiles>O=C(CC(F)(F)F)C1(Cc2ccccc2)CC(=Cc2cccs2)c2cc(Cl)c(Cl)cc2C1=O</smiles>

$2 \mathrm{mf}$<smiles>CCOC(=O)c1ccc2c(c1)C(=Cc1cccs1)CC(Cc1ccccc1)(C(=O)CC(F)F)C2=O</smiles>

$2 \mathrm{mg}$ 2nh $\mathrm{R}=\mathrm{OMe}$<smiles>[R]c1ccc2c(c1)C(=O)C(CC(=O)Oc1ccccc1)(C(=O)O)C/C2=C/c1ccccc1</smiles>

$1 \%$

${ }^{a}$ Reactions were conducted with $0.30 \mathrm{mmol}$ of $\mathbf{1 a}, \mathbf{1 g}, \mathbf{1 m}$ or $1 \mathrm{n}$ in $3 \mathrm{~mL}$ of 1,4-dioxane $/ \mathrm{H}_{2} \mathrm{O}(9: 1)$. Yields are of isolated products.
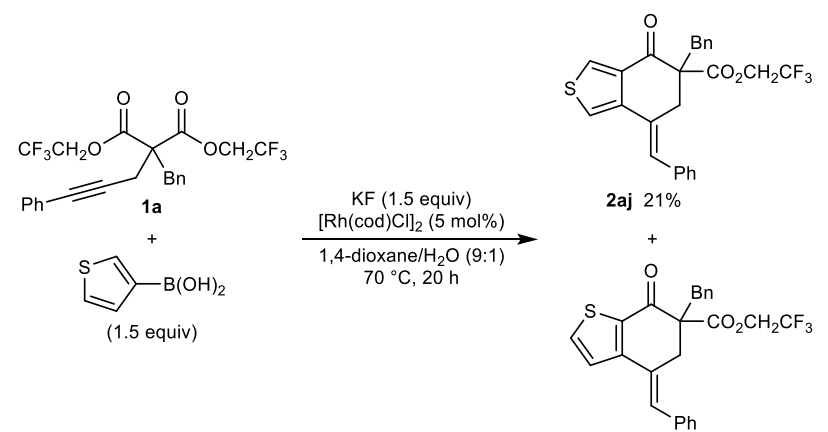

2aj' $42 \%$

two products 2aj and 2aj' were obtained in $21 \%$ and $42 \%$ yield, respectively, resulting from 1,4-Rh(I) migration to different sites of the thiophene prior to cyclization (eqn (1)).

A possible catalytic cycle for these reactions is depicted in Scheme 2, using substrate $\mathbf{1 a}$ and $\mathrm{PhB}(\mathrm{OH})_{2}$ as example reaction partners. Heating a mixture of $[\mathrm{Rh}(\operatorname{cod}) \mathrm{Cl}]_{2}, \mathrm{KF}$, and $\mathrm{H}_{2} \mathrm{O}$ may

generate rhodium hydroxide $4(\mathrm{R}=\mathrm{H})$, which can undergo transmetalation with $\mathrm{PhB}(\mathrm{OH})_{2}$ to give arylrhodium species 5 . Phenylrhodation of the alkyne of $\mathbf{1 a}$ gives alkenylrhodium species $\mathbf{6}$, which then undergoes alkenyl-to-aryl 1,4-Rh(I) migration to give arylrhodium species $\mathbf{7}$. Cyclization of $\mathbf{7}$ by 1,2 -addition onto one of the esters produces rhodium alkoxide $\mathbf{8}$, which collapses to release the product 2aa and regenerate the active rhodium complex $\mathbf{4}$ (which could have a either a trifluoroethoxide or hydroxide counterion).

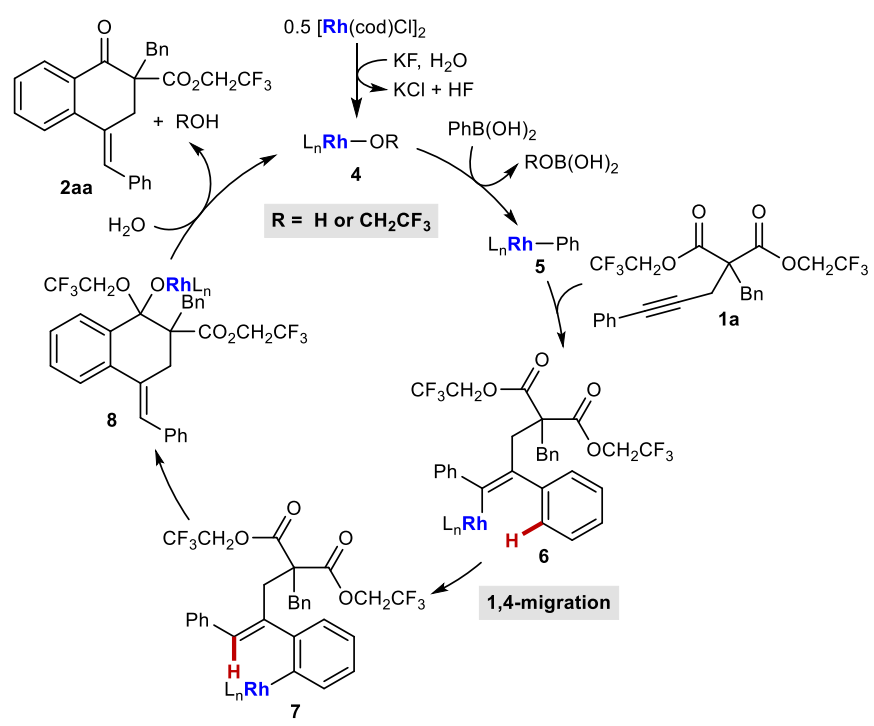

Scheme 2 Possible catalytic cycle

Finally, preliminary efforts at developing an enantioselective variant of this reaction were conducted. After some experimentation, ${ }^{19}$ heating 1a with $\mathrm{PhB}(\mathrm{OH})_{2}$ (1.5 equiv) in the presence of $\left[\mathrm{Rh}\left(\mathrm{C}_{2} \mathrm{H}_{4}\right)_{2} \mathrm{Cl}\right]_{2}(5 \mathrm{~mol} \%),(R)-\mathrm{MeO}-\mathrm{BIHEP}(\mathbf{L 1}, 10$ mol\%), and $\mathrm{KF}$ (1.5 equiv) in 1,4-dioxane $/ \mathrm{H}_{2} \mathrm{O}(9: 1)$ at $70{ }^{\circ} \mathrm{C}$ gave (+)-2aa in $85 \%$ yield and $76 \%$ ee, along with an inseparable mixture of $\mathbf{3 a a}$ and $\mathbf{3 a b}$ in $13 \%$ yield (eqn (2)).

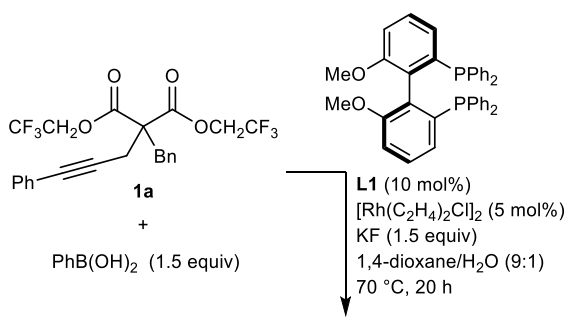<smiles>O=C(OCC(F)(F)F)C(CC=C(c1ccccc1)c1ccccc1)(CC(CC(F)(F)F)(C(=O)OCC(F)(F)F)C(=O)OCC(F)(F)F)C(=O)OCC(F)(F)F</smiles>

In summary, we have developed the rhodium(I)-catalyzed reaction of alkynyl malonates with arylboronic acids to give diverse 1-tetralones. A key step in these arylative cyclizations is an alkenylto-aryl 1,4-Rh(I) migration. Use of a chiral bisphosphine-ligated rhodium complex as the precatalyst gives promising enantioselectivity ( $76 \%$ ee). Our investigations into development of 
new domino reactions involving 1,4-metal migration are ongoing and will be reported in due course..$^{20}$

\section{Conflicts of interest}

There are no conflicts to declare.

\section{Acknowledgements}

This work was supported by the Engineering and Physical Sciences Research Council (EPSRC) Centre for Doctoral Training in Sustainable Chemistry [grant number EP/S022236/1] through a PhD studentship to L.O.; the European Union's Horizon 2020 research and innovation programme [grant number 702386] through a Marie Skłodowska-Curie Individual Fellowship to S.N.K.; the University of Nottingham; and GlaxoSmithKline.

\section{References}

1 For representative examples of catalytic arylative cyclizations of alkynetethered electrophiles, see: (a) R. Shintani, K. Okamoto, Y. Otomaru, K Ueyama and T. Hayashi, J. Am. Chem. Soc., 2005, 127, 54-55. (b) T. Miura, M. Shimada and M. Murakami, J. Am. Chem. Soc., 2005, 127, 1094-1095. (c) R. Shintani, A. Tsurusaki, K. Okamoto and T. Hayashi, Angew. Chem., Int. Ed., 2005, 44, 3909-3912.(d) J. Song, Q. Shen, F. Xu and X. Lu, Org. Lett., 2007, 9, 2947-2950. (e) X. Han and X. Lu, Org. Lett., 2010, 12, 108-111. (f) Z.-T. He, B. Tian, Y. Fukui, X. Tong, P. Tian and G.-Q. Lin, Angew. Chem., Int. Ed., 2013, 52, 5314-5318. ( g) J. Keilitz, S. G. Newman and M. Lautens, Org. Lett., 2013, 15, 1148-1151. (h) Y. Li and M.-H. Xu, Org. Lett., 2014, 16, 2712-2715. (i) Y. Fukui, P. Liu, Q. Liu, Z.-T. He, N.-Y. Wu, P. Tian and G.-Q. Lin, J. Am. Chem. Soc., 2014, 136, 15607-15614. (j) F. Serpier, B. Flamme, J.-L. Brayer, B. Folléas and S. Darses, Org. Lett., 2015, 17, 1720-1723. (k) X. Zhang, X. Xie and Y. Liu, Chem. Sci., 2016, 7, 5815-5820. (l) C. Clarke, C. A Incerti-Pradillos and H. W. Lam, J. Am. Chem. Soc., 2016, 138, 8068 8071. (m) K. Shen, X. Han, X. Lu and Z. Hu, Tetrahedron Lett., 2017, 58, 3768-3771. (n) C. R. Reddy, S. Yarlagadda, B. Sridhar and B. V. S Reddy, Eur. J. Org. Chem., 2017, 5763-5768. (o) C. Yap, G. M. J. Lenagh-Snow, S. N. Karad, W. Lewis, L. J. Diorazio and H. W. Lam, Angew. Chem., Int. Ed., 2017, 56, 8216-8220. (p) S. N. Karad, H Panchal, C. Clarke, W. Lewis and H. W. Lam, Angew. Chem., Int. Ed., 2018, 57, 9122-9125. (q) M. Rajesh, M. K. R. Singam, S. Puri, S. Balasubramanian and M. Sridhar Reddy, J. Org. Chem., 2018, 83, 15361-15371. (r) Y.-X. Tan, X.-Y. Liu, Y.-S. Zhao, P. Tian and G.-Q Lin, Org. Lett., 2019, 21, 5-9.

2 For reviews of 1,4-metal migrations, see: (a) S. Ma and Z. Gu, Angew. Chem., Int. Ed., 2005, 44, 7512-7517. (b) F. Shi and R. C. Larock, Top. Curr. Chem., 2009, 292, 123-164

3 (a) T. Miura, T. Sasaki, H. Nakazawa and M. Murakami, J. Am. Chem Soc., 2005, 127, 1390-1391. (b) R. Shintani and T. Hayashi, Org. Lett. 2005, 7, 2071-2073. (c) R. Shintani, S. Isobe, M. Takeda and T. Hayashi, Angew. Chem., Int. Ed., 2010, 49, 3795-3798. (d) R. Shintani, K Takatsu and T. Hayashi, Angew. Chem., Int. Ed., 2007, 46, 3735-3737. (e) T. Johnson, K.-L. Choo and M. Lautens, Chem. Eur. J., 2014, 20 14194-14197. (f) A. Claraz, F. Serpier and S. Darses, ACS Catal., 2017, 7, 3410-3413. ( $g$ ) A. Selmani, F. Serpier and S. Darses, J. Org. Chem., 2019, 84, 4566-4574.

4 B. M. Partridge, J. Solana González and H. W. Lam, Angew. Chem., Int. Ed., 2014, 53, 6523-6527.

5 J. Yan and N. Yoshikai, ACS Catal., 2016, 6, 3738-3742.

6 For selected examples of other types of 1,4-rhodium(I) migration, see: (a) K. Oguma, M. Miura, T. Satoh and M. Nomura, J. Am. Chem. Soc. 2000, 122, 10464-10465. (b) T. Hayashi, K. Inoue, N. Taniguchi and M. Ogasawara, J. Am. Chem. Soc., 2001, 123, 9918-9919. (c) T. Seiser, O A. Roth, N. Cramer, Angew. Chem., Int. Ed. 2009, 48, 6320-6323. (d) M. Shigeno, T. Yamamoto and M. Murakami, Chem. Eur. J., 2009, 15, 12929-12931. (e) T. Seiser and N. Cramer, Angew. Chem., Int. Ed., 2010, 49, 10163-10167. (f) K. Sasaki, T. Nishimura, R. Shintani, E. A B. Kantchev and T. Hayashi, Chem. Sci., 2012, 3, 1278-1283. (g) J.
Zhang, J.-F. Liu, A. Ugrinov, A. F. X. Pillai, Z.-M. Sun and P. Zhao, J. Am. Chem. Soc., 2013, 135, 17270-17273. (h) R. Shintani, R. Iino and K. Nozaki, J. Am. Chem. Soc., 2014, 136, 7849-7852. (i) H. B. Hepburn and H. W. Lam, Angew. Chem., Int. Ed., 2014, 53, 11605-11610. (j) A. Masarwa, M. Weber and R. Sarpong, J. Am. Chem. Soc., 2015, 137, 6327-6334. (k) B. M. Partridge, M. Callingham, W. Lewis and H. W. Lam, Angew. Chem., Int. Ed., 2017, 56, 7227-7232. (l) M. Callingham, B. M. Partridge, W. Lewis and H. W. Lam, Angew. Chem., Int. Ed., 2017, 56, 16352-16356. (m) J. L. Ming, Q. Shi and T. Hayashi, Chem. Sci., 2018, 9, 7700-7704. (n) T. Miwa and R. Shintani, Org. Lett., 2019, 21, 1627-1631. (o) S.-S. Zhang, T.-J. Hu, M.-Y. Li, Y.-K. Song, X.-D. Yang, C.-G. Feng and G.-Q. Lin, Angew. Chem., Int. Ed., 2019, 58, 3387-3391.

7 For examples of 1,4-rhodium(III) migration, see: (a) D. J. Burns and H. W. Lam, Angew. Chem., Int. Ed., 2014, 53, 9931-9935. (b) D. J. Burns, D. Best, M. D. Wieczysty and H. W. Lam, Angew. Chem., Int. Ed., 2015, 54, 9958-9962. (c) S. E. Korkis, D. J. Burns and H. W. Lam, J. Am. Chem. Soc., 2016, 138, 12252-12257. (d) J. D. Dooley and H. W. Lam, Chem. Eur. J., 2018, 24, 4050-4054. (e) J. Q. Sun, D. C. Bai, P. Y. Wang, K. Wang, G. F. Zheng and X. W. Li, Org. Lett., 2019, 21, 17891793. (f) D. C. Bai, J. T. Xia, F. F. Song, X. Y. Li, B. X. Liu, L. H. Liu, G. F. Zheng, X. F. Yang, J. Q. Sun and X. W. Li, Chem. Sci., 2019, 10, 3987-3993.

8 For examples of other types of 1,4-iridium (I) migration, see ref. 61 and: R. E. Ruscoe, M. Callingham, J. A. Baker, S. E. Korkis and H. W. Lam, Chem. Commun., 2019, 55, 838-841.

9 For examples of other types of 1,4-cobalt (I) migration, see: (a) B.-H. Tan, J. Dong and N. Yoshikai, Angew. Chem., Int. Ed., 2012, 51, 96109614. (b) B. Wu and N. Yoshikai, Angew. Chem., Int. Ed., 2013, 52, 10496-10499. (c) B.-H. Tan and N. Yoshikai, Org. Lett., 2014, 16, $3392-$ 3395.

10 For selected examples of 1,4-palladium migration, see: (a) D. Masselot, J. P. H. Charmant and T. Gallagher, J. Am. Chem. Soc., 2006, 128, $694-$ 695. (b) J. Zhao and R. C. Larock, J. Org. Chem., 2006, 71, 5340-5348. (c) A. Singh and P. R. Sharp, J. Am. Chem. Soc., 2006, 128, 5998-5999. (d) J. Hitce, P. Retailleau and O. Baudoin, Chem. Eur. J., 2007, 13, 792 799. (e) J. Zhao, D. Yue, M. A. Campo and R. C. Larock, J. Am. Chem. Soc., 2007, 129, 5288-5295. (f) M. A. Campo, H. Zhang, T. Yao, A. Ibdah, R. D. McCulla, Q. Huang, J. Zhao, W. S. Jenks and R. C. Larock, J. Am. Chem. Soc., 2007, 129, 6298-6307. (g) T. Kesharwani, A. K. Verma, D. Emrich, J. A. Ward and R. C. Larock, Org. Lett., 2009, 11, 2591-2593. (h) J. Pan, M. Su and S. L. Buchwald, Angew. Chem., Int. Ed., 2011, 50, 8647-8651. (i) T. Piou, A. Bunescu, Q. Wang, L. Neuville and J. Zhu, Angew. Chem., Int. Ed., 2013, 52, 12385-12389. (j) S. K. Bhunia, A. Polley, R. Natarajan and R. Jana, Chem. Eur. J., 2015, 21 16786-16791. (k) M. Wang, X. Zhang, Y. X. Zhuang, Y. H. Xu and T. P. Loh, J. Am. Chem. Soc., 2015, 137, 1341-1347. (l) T. J. Hu, G. Zhang, Y. H. Chen, C. G. Feng and G. Q. Lin, J. Am. Chem. Soc., 2016, 138, 2897-2900. (m) T. J. Hu, M. Y. Li, Q. Zhao, C. G. Feng and G. Q. Lin, Angew. Chem., Int. Ed., 2018, 57, 5871-5875. (n) R. Rocaboy and O. Baudoin, Org. Lett., 2019, 21, 1434-1437.

11 For examples of 1,4-iron migration, see: $(a)$ J. Mo, T. Müller, J. C. A. Oliveira and L. Ackermann, Angew. Chem., Int. Ed., 2018, 57, 77197723. (b) N. Kimura, T. Kochi and F. Kakiuchi, Asian J. Org. Chem., 2019, 8, Early view, DOI 10.1002/ajoc.201900209.

12 (a) D.-S. Hsu and C.-Y. Liou, Org. Biomol. Chem., 2018, 16, 4990-4995. (b) Y. Hernández-Romero, J.-I. Rojas, R. Castillo, A. Rojas and R. Mata, J. Nat. Prod., 2004, 67, 160-167.

13 F.-P. Miao, X.-R. Liang, X.-H. Liu and N.-Y. Ji, J. Nat. Prod., 2014, 77, 429-432.

14 E. Miyoshi, Y. Shizuri and S. Yamamura, Phytochemistry, 1984, 23, 2385-2387.

15 For a relevant review of catalytic carbometalation of alkynes, see: $\mathrm{K}$ Murakami and H. Yorimitsu, Beilstein J. Org. Chem., 2013, 9, 278-302.

16 For catalytic enantioselective arylative cyclizations of bis(2,2,2trifluoroethyl)malonates, see ref. $1 \mathrm{p}$.

17 The structure of 2 ea was further confirmed by X-ray crystallography. CCDC $1938497 \dagger$.

18 See the Supplementary Information for further details.

19 For further details about the evaluation of chiral ligands in these reactions, see the Supplementary Information.

20 The research data associated with this publication can be found at DOI: $10.17639 /$ nott.7008 